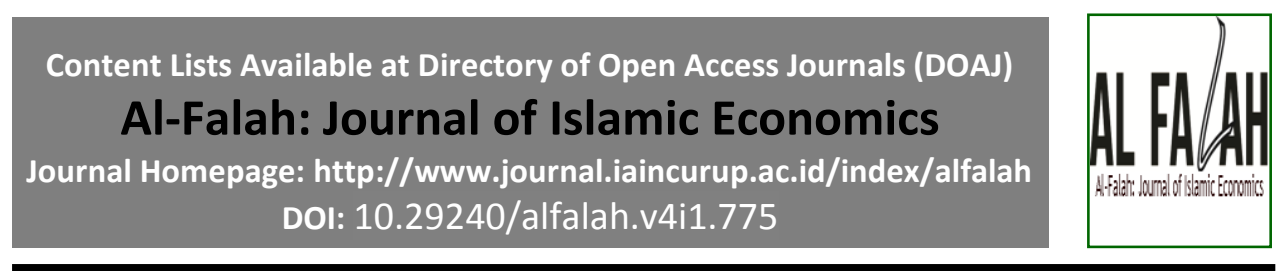

\title{
Efektifitas Penyaluran Dana ZIS : Studi Kasus Pada SMA Terbuka Binaan LAZ Sukses Kota Depok
}

Nurul Ichsan, ${ }^{a^{*}}$ Rona Roudhotul Jannah ${ }^{\mathrm{b}}$

${ }^{a b}$ UIN Syarif Hidayatullah Jakarta

*Email Address: nurul.ichsan@uinjkt.ac.id

\begin{tabular}{l}
\hline ARTICLE INFO \\
\hline Article History: \\
Received 14-03-2019 \\
Revised 29-03-2019 \\
Accepted 16-05-2019 \\
\hline Keywords: \\
ZIS \\
LAZ Sukses \\
Effectiveness \\
School Operational \\
Assistance \\
\\
\hline Paper Type: \\
Research Paper
\end{tabular}

ABSTRACT:
Purpose: This study aims to analyze the effectiveness of the ZIS fund distribution
program in the form of school operational assistance in $S M A$ Terbuka assisted by $L A Z$
Zakat Sukses, Depok.
Design/Method/Approach: There are 4 variables that can measure the level of effectiveness in this study. Among other things, the accuracy of program targets, program socialization, program objectives, and program monitoring. The four variables fall into the range of effective value scales. That is, accuracy of program targets: 3.13. program socialization: 3.25. program objectives: 3.11. program monitoring: 2.94 .

Findings: The final result of the program effectiveness level score shows a value of 3.11 . Meaning that the value is in the range of effective scales. In general, the distribution of ZIS funds in the form of operational assistance in SMA Terbuka assisted by $L A Z$ Zakat Sukses of Depok City has been effective.

Originality/Values: This study contributes extensively in introducing a measurement of how the efectivity of ZIS distribustion, especially in Terbuk a Senior High School which maintained by LAZ Sukses, Depok

\section{ABSTRAK:}

Tujuan: Kajian ini bertujuan menganalisis efektivitas distribusi dana ZIS pada Sekolah SMA Terbuka yang dibina oleh LAZ Zakat Sukses, Depok.

Desain/Metode/Pendekatan: Terdapat 4 variabel yang dapat mengukur tingkat efektivitas pada penelitian ini. Diantaranya, ketepatan sasaran program, sosialisasi program, tujuan program, serta pemantauan program. Keempat variabel tersebut masuk ke dalam rentang skala nilai efektif. Diantaranya, Ketepatan sasaran program: 3,13. Sosialisasi program: 3,25. Tujuan Program: 3,11. Pemantauan program: 2,94.

Temuan: Hasil akhir dari rata-rata skor tingkat efektivitas program menunjukan nilai 3,11. Artinya nilai tersebut masuk dalam rentang skala efektif. Sehingga penyaluran dana ZIS dalam bentuk bantuan operasional sekolah di SMA terbuka binaan LAZ Zakat Sukses Kota Depok telah berjalan efektif.

Originalitas/Novelty: kontribusi kajian ini terletak pada tawarannya terhadap pengukuran efektifitas distribusi dana ZIS, secara khusus pada SMA Terbuka yang dibina oleh LAZ Sukses, Depok. 


\section{PENDAHULUAN}

Pendidikan berperan penting dalam memajukan bangsa dan negara. Pendidikan juga menjadi salah satu faktor kebutuhan dasar manusia dalam mencerdaskan kehidupan bangsa, sehingga melalui pendidikan maka kesejahteraan rakyat dapat terwujud. Melalui pendidikan maka Sumber Daya Manusia bisa lebih berkembang dan dapat menghasilkan manusia yang lebih produktif, sehingga dapat meningkatkan kualitas bangsanya.

Di Indonesia, isi pembukaan UUD 1945 juga menyinggung masalah pendidikan. Yaitu "mencerdaskan kehidupan bangsa". Hal ini membuktikan bahwa pendidikan merupakan salah satu faktor penting dalam menentukan jati diri bangsa. Salah satu strategi Indonesia untuk meningkatkan pendidikan adalah program wajib belajar 12 tahun. Tapi pada kenyataannya data UNICEF menyebutkan bahwa pada tahun 2016 di Indonesia tercatat 2,5 juta anak tidak dapat melanjutkan pendidikannya. Yang diantaranya adalah sebanyak 600 ribu anak usia Sekolah Dasar, dan 1,9 juta anak usia Sekolah Menengah Pertama.

Angka putus sekolah yang terjadi di Indonesia berkaitan erat dengan kemiskinan. Tingkat pendapatan yang rendah menjadi penghambat biaya sekolah anak. Negara seharusnya berperan dan bertanggung jawab dalam penyelenggaraan pendidikan. Namun pemerintah memiliki keterbatasan yang membuatnya sulit dalam menjangkau penyelenggaraan pendidikan ke seluruh warga Indonesia.

Karena pendidikan dan kemiskinan sangat berkaitan erat, Islam sejak lama telah memberikan solusi terhadap permasalahan umat manusia, salah satunya yaitu dalam mengentaskan kemiskinan. Ada beberapa instrumen alternatif yang ditawarkan oleh agama Islam, diantaranya adalah zakat, infak, dan sedekah. Sejak zaman Rasulullah SAW, konsep zakat telah menjadi pilar perekonomian umat. Karena zakat merupakan sumber pendapatan negara yang paling utama dan penting. Nurul Ichsan (2018) dalam jurnalnya mengatakan bahwa penerimaan suatu daulah Islam memang terbesar berasal dari zakat dan pajak, ${ }^{1}$ hal ini bisa dilihat dari sejarah peradaban muslim. Saiful Azhar Rosly (2008) menjelaskan bahwa zakat memainkan peran penting dalam mengentaskan kemiskinan dan redistribusi pendapatan dari orang-orang muslim yang merupakan komponen penting dari keuangan publik dalam Islam. Begitu juga dengan penelitian yang dilakukan oleh Ahmad Fahme Mohd Ali dkk (2015) menjelaskan bahwa pendistribusian dana zakat juga telah terbukti efektif dalam meningkatkan pendapatan bagi penerima zakat di kelantan. ${ }^{2}$

1 Nurul Ichsan, "Tinjauan Penerapan Pungutan Pajak Dan Zakat Menurut Konsep Ekonomi Islam Di Indonesia," Jurnal Islamadina Vol. 19, no. 2 (2018): h. 10.

2 Ali Ahmad Fahme Mohd, "The Effectiveness of Zakat in Reducing Poverty Incident: An Analysis in Kelantan, Malaysia," Asian Social Science Vol. 11, no. 21 (2015): h. 13. 
Potensi zakat di Indonesia terbilang cukup tinggi, apalagi dengan mayoritas penduduk di Indonesia yang beragama Islam. Sehingga pemerintah pun memberikan payung hukum kepada lembaga-lembaga amil zakat dalam mengelola dana ZIS, termasuk upaya-upaya lembaga amil zakat dalam mendapatkan dana tambahan dari mekanisme zakat untuk menyelesaikan masalah perekonomian.

Adapun orang-orang yang menuntut ilmu merupakan salah satu bagian dari golongan orang yang berhak menerima zakat. Dalam hal ini golongan tersebut masuk pada kategori "Fisabilillah". Dengan adanya pengumpulan dana ZIS yang kemudian akan didistribusikan dalam bidang pendidikan, diharapkan akan memberi jalan bagi mereka yang tidak mampu untuk melanjutkan pendidikannya. Agar kemiskinan dan kebodohan yang telah merajalela di negeri ini perlahan dapat segera dientaskan melalui mekanisme zakat yang dikelola oleh lembaga amil zakat.

Lembaga amil zakat di kota Depok pun ikut andil dalam mengurangi angka putus sekolah siswa. Salah satunya adalah program penyaluran dana ZIS untuk pendidikan yang digagaskan oleh LAZ Zakat Sukses kota Depok. Yang menarik dari program tersebut adalah penyaluran dana ZIS yang dilakukannya berbentuk bantuan biaya operasional sekolah untuk SMA Terbuka binaannya yang berlokasi di Cinangka, Depok. SMA Terbuka tersebut merupakan sekolah gratis yang menginduk pada SMAN 5 Depok. LAZ Zakat Sukses sudah hampir 7 tahun ikut andil dalam pembangunan sekolah di SMA Terbuka Cinangka. Setiap bulan LAZ Zakat Sukses rutin memberikan bantuan dana ZIS berupa biaya operasional sekolah.

Sejak awal berdiri, LAZ Zakat Sukses memang sangat fokus terhadap pemberdayaan dhuafa dalam bidang pendidikan di kota Depok. Hal ini sejalan dengan hasil laporan keuangan tahunan yang ada di LAZ Zakat Sukses. Tercatat bahwa pada tahun 2016 sebagian besar dana ZIS disalurkan pada bidang sosial kemanusiaan, yaitu sebesar 3.815 jiwa. Lalu pada urutan kedua, penyaluran dana ZIS sebagian besar disalurkan untuk bidang pendidikan, yaitu sebesar 3.264 jiwa. Hal ini membuktikan bahwa LAZ Zakat Sukses Kota Depok dalam penyaluran dana ZIS

Begitu juga pada laporan penyaluran dana zakat di LAZ Zakat Sukses Kota Depok pada tahun 2016 tercatat bahwa penyaluran dana zakat lebih banyak disalurkan pada mustahik kategori fakir miskin dan fisabilillah, yang masing-masing penyalurannya sebesar 2.429.666.939 rupiah dan 1.032.792.477 rupiah. Fisabilillah dalam kategori ini merupakan orang-orang yang menuntut ilmu. 


\section{Tabel 1.}

Penyaluran Dana Zakat LAZ Zakat Sukses tahun 2016

\begin{tabular}{l|r}
\hline \multicolumn{1}{c|}{ Penyaluran } & Jumlah \\
\hline Amil & 678.622 .876 \\
Fakir Miskin & 2.429 .666 .939 \\
Muallaf & 1.455 .000 \\
Gharimin & 1.000 .000 \\
Fisabilillah & 1.032 .792 .477 \\
Ibnu Sabil & - \\
Riqab & - \\
\hline Jumlah Penyaluran Dana Zakat & $\mathbf{4 . 1 4 3 . 5 3 7 . 2 9 2}$ \\
\hline \multicolumn{2}{c}{ Sumber: Laporan Kenangan 2016 Yayasan Zakat Sukses }
\end{tabular}

Penyaluran dana ZIS dalam bentuk bantuan operasional sekolah yang digagaskan oleh LAZ Zakat Sukses Kota Depok menarik untuk diteliti lebih lanjut Maka perlu dikaji "Efektifitas Penyaluran Dana Zis : Studi Kasus Pada SMA Terbuka Binaan LAZ Sukses Kota Depok." Berdasarkan latar belakang yang telah diuraikan di atas, maka dapat dirumuskan permasalahan dalam penelitian ini, yaitu: "Bagaimana tingkat efektivitas program penyaluran dana ZIS dalam bentuk bantuan operasional sekolah SMA terbuka binaan LAZ Zakat Sukses Kota Depok?" Berdasarkan rumusan masalah di atas, tujuan penelitian ini adalah: "Untuk mengetahui tingkat efektivitas program penyaluran dana ZIS dalam bentuk bantuan operasioanl sekolah SMA terbuka binaan LAZ Zakat Sukses Kota Depok."

\section{LANDASAN TEORI}

Penyaluran dana zakat untuk pendidikan secara umum merupakan persoalan kontemporer. Para ulama kontemporer berbeda pendapat dalam menanggapi penyaluran dana zakat untuk pendidikan. Dalam hal ini, penyaluran dana zakat untuk pendidikan dimasukkan dalam golongan fisabilillah. Kata fisabilillah sering dikaitkan dengan jihad (berperang). Namun bila kita pahami dan menelaah kembali arti kata fisabilillah, ternyata memiliki pengertian yang lebih luas dari arti jihad atau berperang di jalan Allah. Ada tiga pendapat mengenai makna kata fisabilillah. Pendapat pertama, yang dimaksud dengan fisabilillah yaitu jihad atau berperang mengangkat senjata di jalan Allah pada medan pertempuran. Diantara ulama yang memegang pendapat pertama ini adalah Ibn Jarir ath-Thabari dalam karyanya Jami' al-Bayan, dan Imam alQurthubi dalam karyanya al-Jami' Li Ahkam al-Quran. Para ulama pada pendapat ini tidak memperkenankan penggunaan zakat disalurkan untuk pendidikan. Pendapat kedua, bahwa yang dimaksud dengan fisabilillah adalah mereka yang berperang mengangkat senjata di medan perang, dan mereka yang tengah menunaikan haji dan umrah. Diantara ulama yang memegang pendapat 
ini adalah Ibn Katsir dalam buku tafsirnya Tafsir al-Quran al-'Azim, dan Imam asy-Syaukani dalam bukunya Fath al-Qadir.

Dan pendapat ketiga mengatakan bahwa fisabilillah adalah segala sesuatu yang terkait dengan perbuatan kebajikan untuk kemaslahatan umat, seperti membangun jembatan, mendirikan sekolah, masjid, lembaga-lembaga sosial dan pengkafanan mayyit. Para ulama yang memegang pendapat ketiga ini adalah Imam Fakhr ar-Razi dalam karya tafsirnya Tafsir ar-Razi, dan Syeikh Ahmad Musthafa al-Maraghi dalam tafsirnya al-Maraghi.

Yusuf Qardhawi mengartikan fisabilillah dengan jihad, sebagaimana yang diartikan mazhab. Akan tetapi jihad yang dimaksudnya adalah jihad dalam bentuk tulisan, lisan, pemikiran, pendidikan, sosial, budaya serta politik yang kesemuanya itu digunakan untuk keagungan dan kemegahan Islam. Selain itu, mengingat bahwa dunia kita sedang dalam pergumulan globalisme yang mencanangkan tidak ada kekerasan untuk seluruh umat manusia, maka tentu dana ini harus dialihkan penyalurannya dalam bentuk lain dari berjihad di jalan Allah. Bukan mereka yang mengangkat senjata, tapi bagi mereka yang mengangkat pena, menuntut ilmu untuk mengibarkan panji agama Allah di muka bumi ini. ${ }^{3}$

\section{METODE}

\section{Ruang Lingkup Penelitian}

Penelitian yang dilakukan adalah penelitian lapangan dengan menggunakan pendekatan kualitatif dan penjelasan deskriptif. Penelitian kualitatif menurut Moleong (2004) adalah penelitian secara holistik bermaksud untuk memahami fenomena tentang apa yang dialami subjek penelitian, baik itu perilakunya, persepsi, motivasi maupun tindakannya, dan secara deskriptif dalam bentuk kata-kata dan bahasa, ${ }^{4}$ pada suatu konteks khusus yang alamiah dan dengan memanfaatkan berbagai metode alamiah. Di mana penelitian ini merupakan penelitian laporan, pengamatan lapangan yaitu penelitian terhadap data primer melalui wawancara dan kuesioner, serta data sekunder yang didapatkan melalui berbagai sumber langsung maupun tidak langsung.

\section{Metode Penentuan Sampel}

Populasi adalah keseluruhan jumlah yang terdiri atas obyek atau subyek yang mempunyai karakteristik atau kualitas tertentu yang ditetapkan oleh peneliti untuk diteliti dan kemudian ditarik kesimpulannya. ${ }^{5}$ Populasi dalam

${ }^{3}$ M. Arief Mufraini, Akuntansi Dan Manajemen Zakat: Mengkomunikasikan Kesadaran Dan Membangun Jaringan (Jakarta: Kencana, 2012), h. 14.

${ }^{4}$ S. Arikunto, Prosedur Penelitian Suatu Pendekatan Praktek (Jakarta: Rineka Cipta, 2008), h. 50 .

5 V. Wiratna Sujarweni, Metode Penelitian: Lengkap, Praktis, Dan Mudah Dipahami (Yogyakarta: Pustaka Baru Press, 2014), h. 60. 
penelitian ini adalah siswa yang berada di SMA terbuka Cinangka binaan LAZ Zakat Sukses kota Depok. Sampel adalah bagian dari populasi yang dipilih dengan menggunakan prosedur tertentu sehingga diharapkan dapat mewakili populasi. Dalam penelitian ini teknik pengambilan sampel menggunakan hukum nonprobability sampling artinya tidak memberi peluang yang sama bagi seluruh anggota populasi untuk dipilih menjadi anggota sampel. Perwakilan populasi yang dijadikan sampel adalah siswa yang berada di SMA terbuka Cinangka binaan LAZ Zakat Sukses kota Depok.

Menurut Arikunto (2008) Pengambilan sampel jika subjeknya kurang dari 100 orang sebaiknya diambil semuanya, jika subjeknya besar atau lebih dari 100 orang dapat diambil $10-15 \%$ atau $20-25 \%$ atau lebih. Pada penelitian ini penulis mengambil sampel 25\% dari populasi yang ada, yaitu sebesar 40 sampel. Karena populasi atau siswa di SMA Terbuka Cinangka Depok sebesar 160 siswa.

\section{Metode Pengumpulan Data}

Jenis data yang digunakan dalam penelitian ini adalah data primer dan data sekunder. Pengumpulan data dilakukan melalui pemberian kuesioner dan wawancara. Wawancara di sini ditujukan kepada pengelola LAZ Zakat Sukses kota Depok untuk mendapatkan gambaran mengenai program penyaluran dana ZIS dalam bentuk bantuan operasional sekolah SMA terbuka binaan LAZ Zakat Sukses kota Depok. Selanjutnya untuk kuesioner diberikan kepada siswa yang berada di SMA terbuka binaan LAZ Zakat Sukses kota Depok. Data dikumpulkan dengan menggunakan angket tertutup, yaitu mengajukan pertanyaan langsung kepada responden mengenai variabel-variabel penelitian yang telah ditentukan sebelumnya. Dan skala yang dipakai dalam penyusunan kuesioner pada penelitian ini adalah skala likert. Skala likert digunakan untuk mengukur sikap, pendapat dan persepsi seseorang atau sekelompok orang tentang fenomena sosial. ${ }^{6}$ Jawaban setiap item instrumen yang menggunakan skala likert mempunyai gradiasi dari sangat positif sampai sangat negatif. Berikut adalah jenjang yang akan dipakai dalam pengisian kuesioner yaitu ada 4 skor. Skor 1; sangat tidak setuju, skor 2; tidak setuju, skor 3; setuju, dan skor 4; sangat setuju.

${ }^{6}$ Sugiyono, Metode Penelitian Kuantitatif, Kualitatif, Dan R\&D (Bandung: Alfabeta, 2014), h. 70. 


\section{Metode Analisis Data}

Analisis tabulasi sederhana, data yang diperoleh diolah ke dalam bentukpresentase.

$$
P=\frac{f i \times 100 \%}{\sum f i}
$$

\section{Dimana:}

$$
\begin{array}{ll}
\mathrm{p} & \text { : persentasi responden yang memilih kategori tertentu } \\
\mathrm{fi} & : \text { jumlah responden yang memilih kategori tertentu } \\
\Sigma \mathrm{fi} & : \text { banyaknya jumlah responden }
\end{array}
$$

Setiap jawaban responden dari pertanyaan yang diberikan kepada siswa SMA Terbuka Cinangka kemudian diberikan bobot menggunakan skala likert. Cara menghitung skor adalah sebagai berikut:

$$
\bar{x}=\frac{X_{1}+X_{2}+\cdots+X_{n}}{n}
$$

\section{Dimana: \\ Xn : nilai bobot \\ n : jumlah bobot}

Setelah menghitung skor rata-rata, maka selanjutnya adalah menggunakan rentang skala penilaian untuk menentukan posisi tanggapan responden dengan menggunakan nilai skor setiap variabel. Adapun menurut Husein Umar (2011) rumus rentang skala ${ }^{7}$ adalah sebagai berikut :

$$
R s=\frac{R(\text { bobot })}{M}
$$

\section{Dimana: \\ R (bobot) : bobot terbesar - bobot terkecil \\ M : banyaknya kategori}

Karena pada penelitian ini penulis menggunakan skala likert dengan skor 1 sampai 4, maka skala penilaian yang di dapat adalah:

$$
\text { Rs }=(4-1) / 4=0,75
$$

Sehingga posisi keputusan yang di dapat adalah sebagai berikut:

${ }^{7}$ Husein Umar, Metode Penelitian Untuk Skripsi Dan Tesis Bisnis, 2nd ed. (Jakarta: Raja Grafindo Persada, 2011), h. 51. 
Tabel 2.

Rentang Skala Keputusan

\begin{tabular}{cc}
\hline Rentang Skala & Kriteria Keputusan \\
\hline $1,00-1,75$ & Sangat Tidak Efektif \\
$1,76-2,50$ & Tidak Efektif \\
$2,51-3,25$ & Efektif \\
$3,26-4,00$ & Sangat Efektif \\
\hline
\end{tabular}

Sumber: Rumus rentang skala dimodifikasi oleh penulis

Berikut rumus efektivitas program yang telah dimodifikasi penulis berdasarkan penelitian The Nielsen Company dalam mencari EPIC rate atau menentukan efektivitas iklan pada penelitiannya:

Dimana:

$$
\text { Efektivitas Program }=\frac{X 1+X 2+X 3+X 4}{4}
$$

$\begin{array}{ll}\text { X1 } & \text { : Ketepatan Sasaran Program } \\ \text { X2 } & \text { : Sosialisasi Program } \\ \text { X3 } & \text { : Tujuan Program } \\ \text { X4 } & \text { : Pemantauan Program }\end{array}$

\section{Operasional Variabel Penelitian}

Dalam penelitian ini peneliti memiliki instrument penelitian dengan empat variabel dan indikator yang ditujukan untuk mengetahui efektivitas penyaluran dana ZIS dalam bentuk bantuan operasional sekolah. Adapun variabel dalam penelitian ini, yaitu X1; Ketepatan sasaran program, X2; Sosialisasi program, X3; Tujuan program, X4; Pemantauan program.

\section{HASIL DAN PEMBAHASAN}

\section{Efektivitas Program Penyaluran Dana ZIS}

\section{Ketepatan Sasaran Program}

Total skor rata-rata pada variabel ketepatan sasaran program adalah sebagai berikut:

$$
\mathrm{X} \text { Ketepatan Sasaran Program }=\frac{3,03+3,58+3,18+2,95+2,93}{5}=3,13
$$

Berdasarkan hasil total skor rata-rata adalah 3,13. Jika dimasukan ke dalam rentang skala keputusan yang telah dibuat sebelumnya, maka hasilnya menunjukan bahwa variabel ketepatan sasaran program masuk ke dalam rentang skala efektif dengan rata-rata 3,13. Jika mengacu pada hasil total skor rata-rata yang masuk dalam rentang skala efektif, maka hal ini mengindikasikan bahwa 
program yang dijalankan telah sesuai dengan sasaran program. Gambaran untuk sasaran program ini adalah bantuan operasional sekolah yang diberikan oleh LAZ Zakat Sukses kepada SMA Terbuka binaannya meliputi perbaikan infrastruktur sekolah, buku mata pelajaran, alat tulis, dan lain-lain. Sasaran dari program pemberian bantuan operasional sekolah oleh LAZ Zakat Sukses adalah siswa kurang mampu, siswa putus sekolah, dan diprioritaskan untuk siswa muslim. diharapkan pemberian bantuan operasional sekolah ini akan dirasakan manfaatnya oleh para siswa yang bersekolah di SMA Terbuka binaan LAZ Zakat Sukses.

\section{Sosialisasi Program} berikut:

Total skor rata-rata pada variabel sosialisasi program adalah sebagai

$$
\mathrm{X} \text { Sosialisasi Program }=\frac{3,2+2,95+3,55+3,3}{4}=3,25
$$

Berdasarkan hasil total skor rata-rata adalah 3,25. Jika dimasukan ke dalam rentang skala keputusan yang telah dibuat sebelumnya, maka hasilnya menunjukan bahwa variabel sosialisasi program masuk ke dalam rentang skala efektif dengan rata-rata 3,25. Jika mengacu pada total skor rata-rata yang masuk dalam rentang skala efektif, maka hal ini mengindikasikan bahwa LAZ Zakat Sukses telah menjalankan sosialisasi program dengan baik. Gambaran untuk sosialisasi pada program ini adalah Sosialisasi program bantuan oleh LAZ Zakat Sukses kepada SMA Terbuka binaannya mencakup pada penyebarluasan informasi mengenai program penyaluran dana ZIS dalam bentuk bantuan operasional sekolah. Penyebarluasan informasi ini bisa melalui media cetak maupun online. Selain itu LAZ Zakat Sukses juga memberikan sosialisasi kepada para siswa mengenai bantuan yang diberikan. Hal ini dimaksudkan agar para siswa mengetahui bahwa LAZ Zakat Sukses telah memberikan amanah berupa bantuan kepada pihak sekolah yang tujuannya digunakan untuk biaya keperluan operasional sekolah.

\section{Tujuan Program}

Total skor rata-rata pada variabel tujuan program adalah sebagai berikut:

$$
X \text { Tujuan Program }=\frac{3,55+2,95+3,03+2,93}{4}=3,11
$$

Berdasarkan hasil total skor rata-rata adalah 3,11. Jika dimasukan ke dalam rentang skala keputusan yang telah dibuat sebelumnya, maka hasilnya menunjukan bahwa variabel tujuan program masuk ke dalam rentang skala 
efektif dengan rata-rata 3,11. Jika mengacu pada hasil total skor rata-rata yang masuk dalam rentang skala efektif, maka hal ini mengindikasikan bahwa program yang dijalankan telah sesuai dengan tujuan yang diharapkan sebelumnya. Gambaran untuk tujuan pada program ini adalah tujuan yang diharapkan oleh LAZ Zakat Sukses pada program penyaluran dana ZIS dalam bentuk bantuan operasional sekolah di SMA Terbuka binaannya meliputi dapat meningkatkan pembangunan di SMA Terbuka, mampu mengurangi angka putus sekolah siswa, mampu mengurangi beban biaya sekolah siswa, serta mampu mengurangi tingkat kebodohan dan kemiskinan di masyarakat.

\section{Pemantauan Program}

Total skor rata-rata pada variabel pemantauan program adalah sebagai berikut:

$$
\mathrm{X} \text { Pemantauan Program }=\frac{2,95+2,93}{2}=2,94
$$

Berdasarkan hasil total skor rata-rata adalah 2,94. Jika dimasukan ke dalam rentang skala keputusan yang telah dibuat sebelumnya, maka hasilnya menunjukan bahwa variabel tujuan program masuk ke dalam rentang skala efektif dengan rata-rata 2,94. Jika mengacu pada hasil total skor rata-rata yang masuk dalam rentang skala efektif, maka hal ini mengindikasikan bahwa selama program berjalan LAZ Zakat Sukses tetap rutin memantau program dengan baik. Gambaran untuk pemantauan pada program ini adalah setelah program penyaluran dana ZIS dalam bentuk bantuan operasional sekolah di SMA Terbuka binaan LAZ Zakat Sukses berjalan, diharapkan LAZ Zakat Sukses rutin memantau langsung penggunaan dana ZIS yang diberikan, serta ikut memantau perkembangan siswa yang merupakan target utama program atau yang merasakan manfaat dari bantuan dana ZIS tersebut.

\section{Tingkat Efektivitas Program}

Setelah masing-masing variabel didapatkan hasilnya, maka langkah selanjutnya adalah mencari nilai rata-rata efektivitas program. Keempat nilai variabel tadi dijumlahkan untuk mendapatkan nilai rata-rata efektivitas program. Untuk melihat nilai dari keseluruhan variabel, dapat dilihat pada tabel di bawah ini: 
Tabel 3.

Nilai Keseluruhan Variabel

\begin{tabular}{lcc}
\hline \multicolumn{1}{c}{ Variabel } & Skor & Kesimpulan \\
\hline Ketepatan sasaran program & 3,13 & Efektif \\
Sosialisasi program & 3,25 & Efektif \\
Tujuan Program & 3,11 & Efektif \\
Pemantauan Program & 2,94 & Efektif \\
\hline
\end{tabular}

Sumber: Diolah peneliti berdasarkan data kuesioner

$$
\text { Efektivitas Program }=\frac{3,13+3,25+3,11+2,94}{4}=3,11
$$

$\begin{array}{ll}\text { Skala Penilaian: } & \\ 1,00-1,75 & =\text { Sangat Tidak Efektif } \\ 1,76-2,50 & =\text { Tidak Efektif } \\ 2,51-3,25 & =\text { Efektif } \\ 3,26-4,00 & =\text { Sangat Efektif }\end{array}$

Berdasarkan perhitungan di atas, hasil akhir dari nilai efektivitas program adalah 3,11 yang jika dimasukan ke dalam rentang skala penilaian maka masuk dalam kategori efektif. Hal ini membuktikan bahwa program penyaluran dana ZIS dalam bentuk bantuan operasional sekolah telah berjalan efektif dengan rata-rata nilai 3,11. Artinya program yang dijalankan oleh LAZ Zakat Sukses telah memenuhi standar yang telah ditentukan, dengan indikator pengukurannya meliputi ketepatan sasaran program, sosialisasi program, tujuan program, dan pemantauan program.

Dari keempat variabel yang mendapatkan skor terendah adalah variabel pemantauan program. Sehingga LAZ Zakat Sukses harus lebih memperhatikan pemantauan program yang dijalankan. Agar ke depannya bantuan yang diberikan oleh LAZ Zakat Sukses untuk SMA Terbuka binaannya dapat tetap berjalan dengan baik dan tidak terputus di tengah jalan.

\section{SIMPULAN}

Secara keseluruhan program penyaluran dana ZIS dalam bentuk bantuan operasional sekolah yang dijalankan oleh LAZ Zakat Sukses sudah berjalan efektif. Hal ini dilihat dari masing-masing variabel yang mendapatkan nilai rata-rata skor yang masuk dalam rentang skala efektif. Diantaranya, untuk variabel ketepatan sasaran program mendapatkan nilai 3,13 yang masuk dalam rentang skala efektif. Untuk variabel sosialisasi program mendapatkan nilai 3,25 
yang masuk dalam rentang skala efektif. Untuk variabel tujuan program mendapatkan nilai 3,11 yang masuk dalam rentang skala efektif. Dan terakhir untuk variabel pemantaun program mendapatkan nilai 2,94 yang masuk dalam rentang skala efektif. Hingga Hasil akhir rata-rata skor efektivitas program yaitu sebesar 3,11 dan masuk dalam kategori efektif berdasarkan rentang skala penilaian yang telah ditentukam.

Penelitian yang dilakukan oleh Husnul Hami Fahrini (2016) juga mendapatkan hasil yang sama yaitu program penyaluran dana zakat profesi dalam bentuk pemberian beasiswa telah berjalan sangat efektif dengan tingkat efektivitas sebesar $95,58 \%{ }^{8}$ Keduanya menunjukan hasil efektif dalam pendistribusian dana zakat dalam bidang pendidikan. Sehingga hal ini dapat memberikan motivasi dan peluang bagi lembaga zakat yang ada di Indonesia untuk membantu mengurangi angka putus sekolah di masyarakat.

\section{Referensi:}

Agung. "Metode Penelitian Pendidikan", Malang: Aditya Media Publishing, 2014.

Ali, Ahmad Fahme Mohd, dkk. "The Effectiveness of Zakat in Reducing Poverty Incident: An Analysis in Kelantan, Malaysia", Asian Social Science, Vol.11 No.21, 2015.

Al Maraghi, Ahmad Mustafa. "Tafsir Al Maraghi", diterjemahkan oleh Bahrun Abu Bakar dengan judul "Terjemah Tafsir Al Maragbi”, Semarang: CV. Toha Putra Semarang, 1992.

Arikunto, S. "Prosedur Penelitian Suatu Pendekatan Praktek", Jakarta: Rineka Cipta, 2008.

Budiani, Ni Wayan. "Efektivitas Program Penanggulangan Pengangguran Karang Taruna Eka Taruna Bhakti Desa Sumerta Kelod Kecamatan Denpasar Timur Kota Denpasar", Jurnal Ekonomi dan Sosial vol. 2 (1), 2007.

Budiman, M. Arif Kasim dan Izzuddin Edi Siswanto. "Analisis Efektivitas Pendayagunaan Zakat Produktif Pada Program Pemberdayaan Masyarakat Di Wilayah Sukabumi (Studi Kasus: Kampoeng Ternak Dompet Dhuafa)", Jurnal STEI SEBI, 2016.

${ }^{8}$ Husnul Hami Fahrini, "Efektivitas Program Penyaluran Dana Zakat Profesi Dalam Bentuk Pemberian Beasiswa Bagi Siswa Muslim Kurang Mampu Oleh Badan Amil Zakat Nasional (BAZNAS) Di Kabupaten Tabanan Tahun 2015," Jurnal Program Studi Pendidikan Ekonomi Vol. 7, no. 2 (2016): h. 17. 
Eviyati, Nur. "Pengaruh Pemberian Zakat Produktif Dalam Bentuk Beasiswa Ceria dan Lingkungan Keluarga Terbadap Kualitas Prestasi Mustabik Dengan Motivasi Sebagai Variabel Moderasi (Studi Kasus Pada Rumah Zakat Tabun 2010-2013)”, Skripsi UIN Sunan Kalijaga Yogyakarta, 2015.

Fahrini, Husnul Hami. "Efektivitas Program Penyaluran Dana Zakat Profesi Dalam Bentuk Pemberian Beasiswa Bagi Siswa Muslim Kurang Mampu oleh Badan Amil Zakat Nasional (BAZNAS) di Kabupaten Tabanan Tabun 2015”, Jurnal Program Studi Pendidikan Ekonomi Vol.7 No.2, 2016.

Hafidhuddin, Didin. "Zakat dalam Perekonomian Modern”, Jakarta: Gema Insani Press, 2002.

Handoko, T. Hani. "Manajemen Personalia dan Sumber Daya Manusia”, Yogyakarta: BPFE, 2000.

Hasan, M. Ali. "Zakat dan Infak: Salab Satu Solusi Mengatasi Problema Sosial di Indonesia”, Jakarta: Kencana, 2008.

Ichsan, Nurul. "Tinjauan Penerapan Pungutan Pajak dan Zakat Menurut Konsep Ekonomi Islam Di Indonesia”, Jurnal Islamadina.Vol. 19, No.2, 2018.

Leonard dan Suparadi. "Pengarub Konsep Diri, Sikap Siswa pada Matematika, dan Kecemasan Siswa terhadap Hasil Belajar Matematika”, Jurnal Cakrawala. Th. XXIX. No. 3, 2010.

Masruri. "Analisis Efektivitas Program Nasional Pemberdayaan Masyarakat Mandiri Perkotaan (PNPM) (Studi Kasus Pada Kecamacatan Bunyu Kabupaten Bulungan tabun 2010”, Governance and Public Policy, vol. 1 (1), 2014.

Mufraini, M. Arief. "Akuntansi dan Manajemen Zakat: Mengkomunikasikan Kesadaran dan Membangun Jaringan”, Jakarta: Kencana, 2012.

Rosly, S. A. "Malaysia and Islamic Economics", International Center for Education in Islamic Finance (INCEIF), 2008.

Sabiq, Sayyid. "Fiqih Sunnah", diterjemahkan oleh Nor Hasanuddin. Jakarta: Pena Pundi Aksara, 2006.

Siagian, Sondang P. "Administrasi Pembangunan: Konsep, Dimensi dan Strateginya", Jakarta: Penerbit Gita Karya, 2001.

Subianto, Achmad. "Shadaqah, Infak, dan Zakat: Sebagai instrumen untuke membangun Indonesia yang bersih, sehat, dan benar", Jakarta: Yayasan Bermula Dari Kawan, 2004.

Sugiyono, "Metode Penelitian Kuantitatif Kualitatif dan R\&D”, Bandung: Alfabeta, 2008. 
Sujarweni, V. Wiratna. "Metode Penelitian: Lengkap, Praktis, dan Mudah Dipabami", Yogyakarta: Pustaka Baru Press, 2014.

Supriyono, “Sistem Pengendalian Manajemen”, Jakarta: Erlangga, 2000.

Syafaruddin. "Efektivitas Kebijakan Pendidikan: Konsep, strategi, dan aplikasi kebijakan menuju organisasi sekolah efektif”, Jakarta: Rineka Cipta, 2008.

The Nielsen Company. "EPIC Model” , (Online), (http://www.nielsen.com, diakses 27 Januari 2019)

Umar, Husein. "Metode Penelitian Untuk Skripsi dan Tesis Bisnis Edisi II", Jakarta: PT. Raja Grafindo Persada, 2011.

Wulandari, Dwi Ayu. "Pengaruh Zakat Produktif Yang Direalisasikan Dalam Bentuk. Beasiswa Satu Keluarga Satu Sarjana (SKSS) Badan Amil Zakat Nasional (BAZNAS) Provinsi Sumatera Selatan Terbadap Prestasi Mahasiswa Universitas Islam Negeri Raden Fatah Palembang", Skripsi UIN Raden Fatah Palembang, 2017. 